\title{
Effects of a school-based intervention on adherence of 7-9-year-olds to food-based dietary guidelines and intake of nutrients
}

\author{
Asa G Kristjansdottir ${ }^{1}$, Erlingur Johannsson ${ }^{2}$ and Inga Thorsdottir ${ }^{1, *}$ \\ ${ }^{1}$ Faculty of Food Science and Human Nutrition, Unit for Nutrition Research, Landspitali-University Hospital, \\ School of Health Sciences, University of Iceland, IS-101 Reykjavik, Iceland: ${ }^{2}$ Faculty of Sport and Health \\ Sciences, School of Education, University of Iceland, Reykjavik, Iceland
}

Submitted 26 June 2009: Accepted 4 February 2010: First published online 22 April 2010

\begin{abstract}
Objective: To assess the effects of a school-based intervention on the diets of 7-9-year-olds.

Design: Dietary intake of children in second and fourth grades was assessed with 3 d weighed dietary records in autumn 2006 and autumn 2008, before and after a school-based intervention that started in the middle of second grade, and compared with control schools with no intervention. The diet was evaluated by comparison with food-based dietary guidelines (FBDG) and reference values for nutrient intake. The intervention aimed at several determinants of intake: knowledge, awareness, preferences/taste, self-efficacy and parental influence. Nutrition education material was developed for the intervention and implemented in collaboration with teachers. The main focus of the intervention was on fruit and vegetable intake as the children's intake was far from meeting the FBDG on fruit and vegetables at baseline.

Setting: Elementary schools in Reykjavik, Iceland.

Subjects: Complete dietary records were available for 106 children both at baseline and follow-up.

Results: Total fruit and vegetable intake increased by $47 \%$ in the intervention schools (mean: $61 \cdot 3(\mathrm{sD} 126 \cdot 4) \mathrm{g} / \mathrm{d})$ and decreased by $27 \%$ in the control schools (mean: $46 \cdot 5(\mathrm{sD} 105 \cdot 3) \mathrm{g} / \mathrm{d} ; P<0 \cdot 001)$. The majority of the children in the intervention schools did still not meet the FBDG on fruits and vegetables at follow-up. Fibre intake increased significantly in the intervention schools, as well as that of potassium, magnesium, $\beta$-carotene and vitamin $\mathrm{C}$ (borderline).

Conclusions: The school-based intervention in 7-9-year-olds was effective in increasing fruit and vegetable intake, by $47 \%$ increase from baseline, which was mirrored in nutrient intake.
\end{abstract}

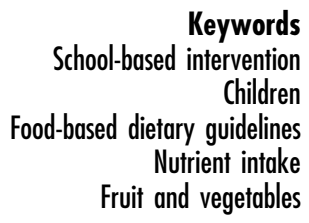

Interventions aiming at promoting healthy eating in children might be expected to yield maximum health benefits in the population. Nutrition education, starting in primary school, is important in promoting healthy diets according to the WHO Global Strategy on Diet, Physical Activity and Health, which encourages governments to provide nutrition education ${ }^{(1)}$. Nutrition is included as a part of human biology and science in Iceland's National Curriculum Guide for Compulsory Schools from the year $2007^{(2)}$. The present intervention consisted of educational material developed with adherence to the curriculum guide and educational strategies related to determinants of food intake. The development of the intervention was based on studies on determinants of food intake ${ }^{(3-6)}$, especially determinants of fruit and vegetable intake ${ }^{(7-13)}$, as well as school-based intervention studies ${ }^{(14-16)}$.
The determinants were availability, knowledge, awareness, preferences, peer and parental influence and self-efficacy, e.g. skills in preparing fruits and vegetables.

The diets of a large group of 7-year-old children were far from meeting the food-based dietary guidelines (FBDG) set for the Icelandic population ${ }^{(17)}$ in a baseline study in autumn 2006 before the school-based intervention ${ }^{(18)}$. A large majority of the 7-year-old children did not meet the FBDG on fruit and vegetable intake. This is consistent with other studies on fruit and vegetable intake in Icelandic children; of the nine European countries participating in the Pro Children cross-sectional study, Iceland had the lowest intake of fruits and vegetables ${ }^{(19)}$. Studies carried out by the Unit for Nutrition Research on diet in childhood have shown that traditional high fish consumption has decreased over the last few decades, intake of vitamin D is low and 
dairy consumption has decreased ${ }^{(20,21)}$. At baseline, in 2006, approximately half of the 7-year-old children met the recommendation to eat fish at least twice a week ${ }^{(18)}$. Fewer met the recommendation to use fish liver oil. Two-thirds of the children met the milk recommendation, i.e. to consume approximately two portions per day.

The present intervention was part of the school-based intervention study 'Lifestyle of 7-9-year-old children'. The aim of the study was to better integrate physical activity into the daily routine at school and to find ways to promote healthy food habits, i.e. increase intake of fruits and vegetables, fish and the use of fish liver oil, and promote moderate intake of milk and milk products. The main focus of the intervention was on fruit and vegetable intake, as children's intake was far from meeting the FBDG on fruit and vegetable intake. The aim of the present study was to assess the effects of a school-based intervention on the diets of 7-9-year-olds. Diet was evaluated by comparison with the FBDG and reference values for nutrient intake.

\section{Materials and methods}

\section{Study population}

The design of the study is shown in Fig. 1. Baseline measurements were made in autumn 2006, when the children were starting the second grade, in six randomly selected schools in Reykjavik. The follow-up measurements were made at the end of the intervention in autumn 2008. The schools were paired for similarity of size and the quarters of Reykjavik in which they were located ${ }^{(22)}$; the two schools in each pair were then randomly assigned to the intervention or control group. Data were collected for 2 weeks in each school, in same sequence from September to November 2006 and 2008. Written consent of both parent and child was secured before measurements at baseline and followup. Height and weight were measured by a physician, using a validated scale (model 708; Seca, Hamburg, Germany), at both baseline and follow-up. At baseline 265 children were invited to participate in the present study; 216 returned dietary records (18\% dropouts). At follow-up, all children who participated in the baseline study and were still in the same school were invited to participate; 171 returned dietary records ( $21 \%$ dropouts). The diets of 165 children were studied at baseline after excluding under-reports ${ }^{(18)}$, and of 130 children at follow-up. A total of 106 children were included in the data analysis at baseline and follow-up, and their dietary records were used for the analysis in the present intervention study (Fig. 2).

Approval for the study was obtained from the National Bioethics Committee (VSN b2006050002/03) and the Icelandic Data Protection Commission.

\section{Intervention programme}

The main focus in the intervention was on increasing fruit and vegetable intake, as the children's intake was far

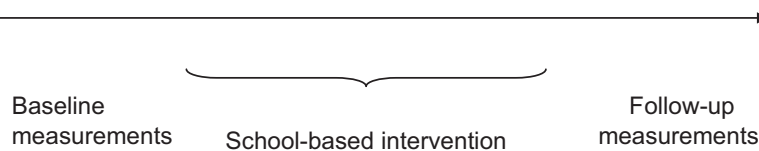

Fig. 1 Design of the study. Baseline measurements were performed in autumn 2006, when the children were starting second grade. The intervention started in the middle of the second grade and the follow-up measurements were performed at the end of the intervention in autumn 2008

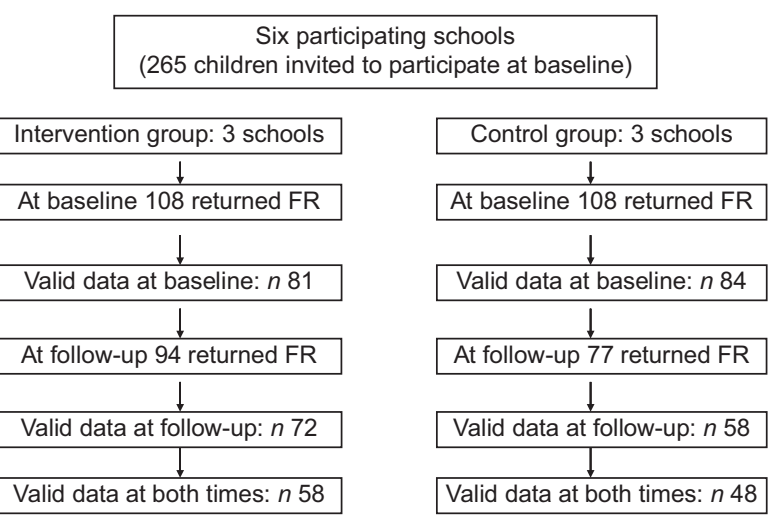

Fig. 2 Flow chart showing participation at baseline and followup in intervention and control groups. At baseline, 265 children were invited to participate; 216 returned food records (FR; $18 \%$ dropout). At follow-up, all children who participated in the baseline study and were still at the same school were invited to participate; 171 returned dietary records ( $21 \%$ dropout)

from meeting the FBDG on fruits and vegetables. The aim was to increase fruit and vegetable intake in the intervention group by at least $20 \%$. Table 1 shows selected educational strategies related to the determinants of fruit and vegetable intake used. In addition, the FBDG on fish, fish liver oil and milk intake were the focus of the educational material and homework assignments, as well as letters to parents.

There were regular meetings with the teachers in the intervention schools from summer 2006 to autumn 2008. At the start of the intervention, the educational material was implemented by the author in collaboration with the teachers in a similar way in all the three intervention schools. Educational material for the teachers to use in the classrooms was subsequently developed in 2007, also in collaboration with the teachers themselves. The new material was implemented by the teachers in the spring term 2008. This material was based on previous experience and publications, e.g. a book by Connie Evers on how to teach nutrition to children ${ }^{(23)}$. The setup of the educational material was modelled on popular Icelandic school books ${ }^{(24)}$. The material for the present intervention consisted of a teacher's book and a workbook for the children. It included seven sections, each section with 
Table 1 Selected educational strategies related to the learning objective and determinants of fruit and vegetable intake used in the present intervention

\begin{tabular}{|c|c|c|c|c|c|c|c|c|c|}
\hline \multirow[b]{2}{*}{ Learning objective } & \multirow[b]{2}{*}{ Activity } & \multicolumn{8}{|c|}{ Determinants } \\
\hline & & Availability & Knowledge & Awareness & $\begin{array}{l}\text { Preference/ } \\
\text { taste }\end{array}$ & $\begin{array}{c}\text { Peer } \\
\text { influence }\end{array}$ & $\begin{array}{l}\text { Parental } \\
\text { influence }\end{array}$ & $\begin{array}{l}\text { Skills } \\
\text { prepare }\end{array}$ & $\begin{array}{l}\text { Ask/ } \\
\text { obtain }\end{array}$ \\
\hline $\begin{array}{l}\text { Children are aware of the } \\
\text { importance of fruit and } \\
\text { vegetable intake for health and } \\
\text { well-being }\end{array}$ & Education workbook-guided activities & & $x$ & & & & & & \\
\hline Children know recommendations & Education workbook-guided activities & & $\mathrm{x}$ & & & & & & \\
\hline $\begin{array}{l}\text { Children are aware of their own } \\
\text { intake and recommendations }\end{array}$ & $\begin{array}{l}\text { Home worksheet - the recommendation } \\
\text { children marked on a graph how often } \\
\text { they ate fruits and vegetables each day for } \\
1 \text { week }\end{array}$ & & $x$ & $x$ & & & $x$ & & \\
\hline $\begin{array}{l}\text { Children eat fruits together at } \\
\text { school and are exposed to }\end{array}$ & $\begin{array}{l}\text { Children brought fruits and vegetables to } \\
\text { school and ate in classroom }\end{array}$ & & & & & $x$ & $x$ & & $x$ \\
\hline different fruits and vegetables & School meals & $\mathrm{x}$ & & & & $\mathrm{x}$ & & & \\
\hline $\begin{array}{l}\text { Children taste 'new' fruits and } \\
\text { vegetables }\end{array}$ & $\begin{array}{l}\text { Home worksheet - children listed which } \\
\text { fruits and vegetables they had tasted and } \\
\text { tested something 'new' }\end{array}$ & & & & $\mathrm{x}$ & & $\mathrm{x}$ & & \\
\hline \multirow[t]{2}{*}{$\begin{array}{l}\text { Children know how to prepare } \\
\text { fruits and vegetables }\end{array}$} & $\begin{array}{l}\text { Home worksheet - children prepared fruit } \\
\text { and vegetable salad at home and brought } \\
\text { the recipe of their favourite salad to } \\
\text { school; the recipes were then put on the } \\
\text { homepage of the study }\end{array}$ & & & & & & $x$ & $\mathrm{x}$ & \\
\hline & $\begin{array}{l}\text { In school, home economics - children } \\
\text { prepared a dinner party, with different } \\
\text { kinds of fruits and vegetables, for their } \\
\text { parents (one school) - children prepared } \\
\text { fruit and vegetables in school for their } \\
\text { classmates (one school) }\end{array}$ & & & & & $\mathrm{x}$ & $\mathrm{x}$ & $x$ & \\
\hline Parents know recommendations & $\begin{array}{l}\text { Letters to parents with information on the } \\
\text { recommendations and the determinants of } \\
\text { fruit and vegetable intake, such as } \\
\text { availability, eating fruits and vegetables } \\
\text { together and family rules }\end{array}$ & $x$ & & & & & $\mathrm{x}$ & & \\
\hline
\end{tabular}


several assignments among which the teachers could choose. The homework assignments were the same in all schools. At all of the intervention schools teachers encouraged children to bring fruits and vegetables to school. Parents' involvement consisted of parental letters and their children's homework assignments. The letters informed the parents about the aims of the intervention and included tips on how to promote healthy food habits in children. The present study was part of the study 'Lifestyle of 7-9-year-old children', a homepage for which was opened in autumn 2007 with weekly letters to parents about nutrition and physical activity (http://www.lifsstill.khi.is). Meetings with activities for the families were held at the schools during the intervention period, where questions from parents were answered by the project's staff. There was a meeting with the chefs of the school canteens, in autumn 2007, in which the aims of the intervention were presented.

\section{Assessments}

The records were continuous over $3 \mathrm{~d}$ - two weekdays and one weekend day. Instructions on how to record the diet were given at meetings with parents at the time of the baseline measurements and written instructions were included in the food record sheet at baseline and follow-up. Parents were provided with accurate electronic scales (PHILIPS HR 2393, Hungary; design and quality of Philips Holland) and were asked to record all items of food and drink, as well as vitamin supplements. All food items were weighed for each child, except the school meal, which was recorded for each child by a trained nutritionist. Standard portion sizes as served in each school were weighed, and were adjusted for leftovers and refills for each child.

\section{Data handling}

Records in which energy intake (EI) was less than the estimated basal metabolic rate (BMR) times $1 \cdot 2$ were classified as under-reports, as evidence has shown that this indicates gross under-reporting ${ }^{(25)}$. The equations from the Nordic Nutrition Recommendations ${ }^{(26)}$ for calculating the average BMR $(\mathrm{MJ} / \mathrm{d})=$ basal energy expenditure $(\mathrm{MJ} / \mathrm{d})$ for children, based on body weight (W, $\mathrm{kg}$ ) and height $(\mathrm{H}, \mathrm{m})$, were used: $\mathrm{BMR}_{\text {girls }}=0 \cdot 071 \mathrm{~W}+0.68$ $\mathrm{H}+1.55$ and $\mathrm{BMR}_{\text {boys }}=0.082 \mathrm{~W}+0.55 \mathrm{H}+1.74$. In the equations, body weight for overweight children was defined as within the international limit for BMI for normal weight (defined for gender and age), replaced by the highest cut-off point for BMI for normal weight ${ }^{(27)}$.

Nutrient calculations were performed with ICEFOOD (a program of the Icelandic Nutrition Council), using the Icelandic Nutrient Database (revised), as well as the Icelandic Nutrition Council Recipe Database 2002. All food and drink was included in the data analysis; fish liver oil was included in the data analysis but not other vitamin supplements.

\section{Statistical analysis}

The statistical analysis was carried out using Statistical Package for Social Sciences statistical software package version $11 \cdot 0$ for Windows (SPSS Inc., Chicago, IL, USA). The level of significance was $P<0 \cdot 05$. Food and nutrient intakes were checked for normality by inspection and by using the Kolmogorov-Smirnov test. Food intake was generally skewed, and there were some zero values; therefore a non-parametric test (Mann-Whitney $U$ test) was used for the analysis of difference in food intake. An independent sample $t$ test was used for the analysis of difference in nutrient intake, except when the distribution of intake of nutrients was skewed. A one-sided $t$ test was used to assess whether the difference between nutrient intake and the recommendations was significant.

\section{Results}

Table 2 shows food intake in both school groups, intervention and control schools, at baseline and follow-up. At baseline, the intake of several food items differed between the groups; among these were fruits and vegetables, as shown in the table. At follow-up, the intakes of raw vegetables, cooked vegetables and total vegetables, and total intake of fruits and vegetables and fish were higher in the intervention schools compared with the control schools, and the intake of candy was lower. At follow-up, $50 \%$ of the children at the intervention schools had fruit intake of approximately $\geq 100 \mathrm{~g} / \mathrm{d}$, vegetable intake of approximately $\geq 60 \mathrm{~g} / \mathrm{d}$ and total fruit and vegetable intake of approximately $\geq 200 \mathrm{~g} / \mathrm{d}$. In the control schools, these values were similar for fruit intake but lower for vegetable intake. Table 3 shows the mean of the individual difference in food intake between baseline and follow-up in both school groups. The main effect of the intervention was on fruit and vegetable intake: the total fruit and vegetable intake increased by approximately $60 \mathrm{~g}$ in the intervention schools, fruit intake by approximately $25 \mathrm{~g}$ and raw vegetable intake by approximately $37 \mathrm{~g}$. The total fruit and vegetable intake decreased at the same time in the control schools, in total $46 \mathrm{~g}$, mainly because of decrease in fruit intake. The most consumed fruits were apples, bananas, oranges and pears, and the most consumed vegetables were raw cucumber, carrots and tomatoes.

Macro- and micronutrient intakes, in both school groups at baseline and at follow-up, are shown in Tables 4 and 5. The macro- and micronutrient intakes were similar in both school groups at baseline, except for a few nutrients, as shown in the tables. At follow-up, the intake and the percentage of energy from MUFA were higher in the intervention schools compared with the control schools; the ratio of $n-6$ to $n$-3 PUFA and the percentage of energy from carbohydrates were lower. Iodine intake was higher in the intervention schools at 
Table 2 Food intake, median intake (25th and 75th percentiles), shown at baseline and follow-up separately for intervention and control schools

\begin{tabular}{|c|c|c|c|c|c|c|c|c|c|c|c|c|c|c|}
\hline \multirow[b]{4}{*}{ Food items $(\mathrm{g} / \mathrm{d})$} & \multicolumn{7}{|c|}{ Baseline } & \multicolumn{7}{|c|}{ Follow-up } \\
\hline & \multicolumn{3}{|c|}{ Intervention ( $n$ 58) } & \multicolumn{3}{|c|}{ Control ( $n$ 48) } & \multirow[b]{3}{*}{$P$ value } & \multicolumn{3}{|c|}{ Intervention ( $n$ 58) } & \multicolumn{3}{|c|}{ Control ( $n$ 48) } & \multirow[b]{3}{*}{$P$ value } \\
\hline & \multirow[b]{2}{*}{ Median } & \multicolumn{2}{|c|}{ Percentiles } & \multirow[b]{2}{*}{ Median } & \multicolumn{2}{|c|}{ Percentiles } & & \multirow[b]{2}{*}{ Median } & \multicolumn{2}{|c|}{ Percentiles } & \multirow[b]{2}{*}{ Median } & \multicolumn{2}{|c|}{ Percentiles } & \\
\hline & & 25th & 75th & & 25th & 75th & & & 25th & 75th & & 25th & 75th & \\
\hline Fruits total & $84 \cdot 7$ & $35 \cdot 8$ & $159 \cdot 5$ & $149 \cdot 7$ & $82 \cdot 4$ & $191 \cdot 8$ & 0.003 & $94 \cdot 2$ & $48 \cdot 3$ & $186 \cdot 4$ & $110 \cdot 3$ & $53 \cdot 8$ & $168 \cdot 3$ & 0.775 \\
\hline Raw vegetables & $30 \cdot 3$ & $8 \cdot 5$ & $59 \cdot 5$ & $19 \cdot 6$ & $1 \cdot 7$ & $51 \cdot 8$ & 0.233 & $57 \cdot 0$ & $19 \cdot 2$ & $101 \cdot 7$ & $17 \cdot 7$ & $2 \cdot 1$ & $36 \cdot 0$ & $<0.001$ \\
\hline Cooked vegetables & $0 \cdot 0$ & 0.0 & $2 \cdot 1$ & $0 \cdot 0$ & 0.0 & $15 \cdot 3$ & 0.028 & $8 \cdot 3$ & 0.0 & $17 \cdot 3$ & $0 \cdot 0$ & $0 \cdot 0$ & $8 \cdot 3$ & 0.020 \\
\hline Vegetables total & $38 \cdot 0$ & $13 \cdot 5$ & $70 \cdot 6$ & $31 \cdot 0$ & $11 \cdot 5$ & $59 \cdot 8$ & 0.698 & $61 \cdot 5$ & $29 \cdot 4$ & $128 \cdot 3$ & $26 \cdot 7$ & $13 \cdot 3$ & $48 \cdot 9$ & $<0.001$ \\
\hline Fruits and vegetables & $129 \cdot 8$ & $72 \cdot 6$ & $220 \cdot 8$ & $173 \cdot 0$ & $110 \cdot 8$ & $247 \cdot 3$ & 0.032 & $199 \cdot 7$ & $125 \cdot 0$ & $272 \cdot 0$ & $139 \cdot 2$ & $81 \cdot 3$ & $201 \cdot 8$ & 0.010 \\
\hline Fish $^{*}$ & $24 \cdot 0$ & 0.0 & $45 \cdot 0$ & 0.0 & 0.0 & $26 \cdot 9$ & 0.028 & $28 \cdot 8$ & $20 \cdot 8$ & $43 \cdot 2$ & $15 \cdot 3$ & 0.0 & $30 \cdot 6$ & $<0.001$ \\
\hline Fish liver oil & 0.0 & 0.0 & $3 \cdot 3$ & 0.0 & 0.0 & $2 \cdot 7$ & $0 \cdot 728$ & 0.0 & 0.0 & $2 \cdot 7$ & 0.0 & 0.0 & $3 \cdot 3$ & 0.748 \\
\hline Milk drinks total & $292 \cdot 8$ & $222 \cdot 9$ & $345 \cdot 2$ & $196 \cdot 0$ & $117 \cdot 9$ & $377 \cdot 8$ & 0.076 & $274 \cdot 7$ & $182 \cdot 9$ & $346 \cdot 7$ & $238 \cdot 7$ & $118 \cdot 1$ & $323 \cdot 9$ & $0 \cdot 159$ \\
\hline Fermented milk & $72 \cdot 3$ & 0.0 & $171 \cdot 3$ & $103 \cdot 7$ & $34 \cdot 9$ & $171 \cdot 7$ & 0.412 & $81 \cdot 7$ & $12 \cdot 5$ & $153 \cdot 3$ & $82 \cdot 5$ & $12 \cdot 9$ & $157 \cdot 5$ & $0 \cdot 813$ \\
\hline Cheese & $6 \cdot 8$ & 0.5 & $18 \cdot 3$ & $7 \cdot 7$ & 0.0 & $12 \cdot 9$ & 0.558 & $14 \cdot 7$ & $3 \cdot 6$ & $27 \cdot 3$ & $9 \cdot 0$ & $3 \cdot 3$ & $23 \cdot 9$ & 0.377 \\
\hline Meat ${ }^{\star}$ & $45 \cdot 5$ & $24 \cdot 7$ & $63 \cdot 4$ & $55 \cdot 8$ & $32 \cdot 2$ & $88 \cdot 7$ & $0 \cdot 212$ & $42 \cdot 9$ & $20 \cdot 7$ & $60 \cdot 5$ & $40 \cdot 0$ & $18 \cdot 4$ & $66 \cdot 9$ & 0.977 \\
\hline Bread & $65 \cdot 3$ & $43 \cdot 3$ & $94 \cdot 6$ & $52 \cdot 3$ & $40 \cdot 4$ & $72 \cdot 6$ & 0.093 & $79 \cdot 5$ & $52 \cdot 3$ & $109 \cdot 3$ & $91 \cdot 2$ & $47 \cdot 0$ & $126 \cdot 4$ & 0.437 \\
\hline Breakfast cereal & $35 \cdot 8$ & $20 \cdot 5$ & $46 \cdot 3$ & $31 \cdot 0$ & $12 \cdot 3$ & $44 \cdot 2$ & $0 \cdot 404$ & $42 \cdot 0$ & $19 \cdot 5$ & $65 \cdot 0$ & $37 \cdot 5$ & $24 \cdot 3$ & $79 \cdot 7$ & 0.829 \\
\hline Biscuit and cakes & $26 \cdot 7$ & $6 \cdot 5$ & $56 \cdot 8$ & $47 \cdot 7$ & $25 \cdot 3$ & $80 \cdot 9$ & 0.002 & $41 \cdot 0$ & $19 \cdot 8$ & $50 \cdot 4$ & $35 \cdot 2$ & $15 \cdot 1$ & $48 \cdot 1$ & 0.238 \\
\hline Chips and French fries & $1 \cdot 2$ & $0 \cdot 0$ & $20 \cdot 4$ & $0 \cdot 0$ & 0.0 & $22 \cdot 3$ & 0.907 & $3 \cdot 2$ & 0.0 & $21 \cdot 1$ & $9 \cdot 2$ & 0.0 & $29 \cdot 1$ & 0.419 \\
\hline Pure fruit juice & $54 \cdot 5$ & 0.0 & $133 \cdot 3$ & $27 \cdot 2$ & 0.0 & $114 \cdot 8$ & $0 \cdot 788$ & 0.0 & 0.0 & $104 \cdot 6$ & 0.0 & $0 \cdot 0$ & $80 \cdot 0$ & 0.461 \\
\hline Sweetened beverages & $66 \cdot 7$ & 0.0 & $152 \cdot 4$ & $70 \cdot 0$ & 0.0 & $179 \cdot 2$ & 0.622 & $111 \cdot 7$ & $25 \cdot 0$ & $268 \cdot 4$ & $120 \cdot 2$ & $12 \cdot 7$ & $302 \cdot 2$ & $0 \cdot 813$ \\
\hline Candy & $6 \cdot 5$ & $0 \cdot 0$ & $28 \cdot 7$ & $12 \cdot 3$ & 0.0 & $29 \cdot 8$ & 0.554 & 0.0 & 0.0 & $19 \cdot 0$ & $11 \cdot 7$ & $0 \cdot 0$ & $39 \cdot 3$ & 0.021 \\
\hline
\end{tabular}

$P$ values shown are for the difference between control and intervention schools at baseline and follow-up (Mann-Whitney $U$ test).

${ }^{*}$ Fish and meat do not include processed fish and meat, such as fish fingers and hot dogs.

Table 3 Difference between food intake at baseline and follow-up in intervention and control schools

\begin{tabular}{|c|c|c|c|c|c|}
\hline \multirow[b]{2}{*}{ Food items $(\mathrm{g} / \mathrm{d})$} & \multicolumn{2}{|c|}{ Intervention ( $n$ 58) } & \multicolumn{2}{|c|}{ Control (n 48) } & \multirow[b]{2}{*}{$P$ value } \\
\hline & Mean & SD & Mean & SD & \\
\hline Fruits total & $24 \cdot 6$ & $114 \cdot 3$ & $-39 \cdot 4$ & $90 \cdot 6$ & 0.001 \\
\hline Raw vegetables & $28 \cdot 8$ & $48 \cdot 8$ & $-7 \cdot 1$ & $40 \cdot 4$ & $<0.001$ \\
\hline Cooked vegetables & $7 \cdot 9$ & $21 \cdot 6$ & 0.0 & $26 \cdot 1$ & 0.003 \\
\hline Vegetables total & $36 \cdot 6$ & $55 \cdot 4$ & $-7 \cdot 1$ & $49 \cdot 2$ & $<0.001$ \\
\hline Fruits and vegetables & $61 \cdot 3$ & $126 \cdot 4$ & $-46 \cdot 5$ & $105 \cdot 3$ & $<0.001$ \\
\hline Fish* & $10 \cdot 6$ & $26 \cdot 6$ & $6 \cdot 9$ & $31 \cdot 3$ & 0.390 \\
\hline Fish liver oil & $-0 \cdot 2$ & $2 \cdot 7$ & 0.5 & $2 \cdot 5$ & 0.231 \\
\hline Total milk drinks & $-15 \cdot 7$ & $167 \cdot 9$ & $-5 \cdot 2$ & $167 \cdot 3$ & 0.725 \\
\hline Fermented milk products & $-11 \cdot 3$ & $110 \cdot 3$ & $-20 \cdot 0$ & $123 \cdot 7$ & 0.661 \\
\hline Cheese & 4.9 & $19 \cdot 8$ & $6 \cdot 2$ & $16 \cdot 7$ & 0.884 \\
\hline Meat* & $-6 \cdot 5$ & $40 \cdot 1$ & $-16 \cdot 9$ & $40 \cdot 8$ & 0.256 \\
\hline Bread & $13 \cdot 9$ & $55 \cdot 9$ & $34 \cdot 8$ & $52 \cdot 4$ & $0 \cdot 188$ \\
\hline Breakfast cereal & $3 \cdot 0$ & $29 \cdot 2$ & $2 \cdot 6$ & $30 \cdot 0$ & 0.744 \\
\hline Biscuit and cakes & $15 \cdot 5$ & $50 \cdot 4$ & $-4 \cdot 8$ & $68 \cdot 1$ & 0.054 \\
\hline Chips and French fries & 0.5 & $23 \cdot 5$ & -0.3 & $26 \cdot 2$ & 0.737 \\
\hline Fruit juice (100\% pure) & $-16 \cdot 1$ & $147 \cdot 1$ & $-21 \cdot 7$ & $126 \cdot 0$ & $0 \cdot 810$ \\
\hline Sweetened beverages & $66 \cdot 2$ & $140 \cdot 5$ & $71 \cdot 9$ & $204 \cdot 2$ & 0.980 \\
\hline Candy & $-4 \cdot 6$ & $23 \cdot 9$ & $1 \cdot 8$ & $32 \cdot 2$ & $0 \cdot 118$ \\
\hline
\end{tabular}

$P$ values shown are for the intervention effect (Mann-Whitney $U$ test).

${ }^{*}$ Fish and meat do not include processed fish and meat, such as fish fingers and hot dogs.

baseline and follow-up. Magnesium and $\beta$-carotene intakes were higher in the intervention schools at followup. Table 6 shows the mean of the individual difference in macro- and micronutrient intakes between baseline and follow-up in both school groups. Percentage of energy from MUFA and the intakes of fibre, potassium, magnesium, copper and $\beta$-carotene increased in the intervention schools compared with the control schools, and vitamin $\mathrm{C}$ increase was of borderline significance.
Table 7 shows the percentage of children meeting the FBDG; the majority of the children did not meet the FBDG for fruits and vegetables at follow-up.

No gender difference in food intake in intervention and control schools was detected at baseline, when separately analysed for the intervention and control schools. When both school groups were analysed together, a gender difference was found for the intake of fish and fish liver oil, the intake being greater among boys. At follow-up, a 
Table 4 Macronutrients, median intake (25th and 75th percentiles), shown at baseline and follow-up separately for intervention and control schools

\begin{tabular}{|c|c|c|c|c|c|c|c|c|c|c|c|c|c|c|}
\hline \multirow[b]{4}{*}{ Macronutrients } & \multicolumn{7}{|c|}{ Baseline } & \multicolumn{7}{|c|}{ Follow-up } \\
\hline & \multicolumn{3}{|c|}{ Intervention ( $n$ 58) } & \multicolumn{3}{|c|}{ Control (n 48) } & \multirow[b]{3}{*}{$P$ value } & \multicolumn{3}{|c|}{ Intervention ( $n$ 58) } & \multicolumn{3}{|c|}{ Control (n 48) } & \multirow[b]{3}{*}{$P$ value } \\
\hline & \multirow[b]{2}{*}{ Median } & \multicolumn{2}{|c|}{ Percentiles } & \multirow[b]{2}{*}{ Median } & \multicolumn{2}{|c|}{ Percentiles } & & \multirow[b]{2}{*}{ Median } & \multicolumn{2}{|c|}{ Percentiles } & \multirow[b]{2}{*}{ Median } & \multicolumn{2}{|c|}{ Percentiles } & \\
\hline & & 25th & 75th & & 25th & 75th & & & 25th & 75th & & 25th & 75th & \\
\hline Energy (kJ) & $6915 \cdot 7$ & $6019 \cdot 5$ & $7926 \cdot 2$ & $6936 \cdot 6$ & $6174 \cdot 4$ & $8089 \cdot 7$ & 0.375 & $7705 \cdot 2$ & $6923 \cdot 8$ & $8665 \cdot 1$ & $7829 \cdot 4$ & $6925 \cdot 2$ & $8939 \cdot 3$ & 0.738 \\
\hline Protein $(g)$ & $66 \cdot 9$ & $57 \cdot 2$ & $81 \cdot 1$ & $62 \cdot 6$ & 54.5 & $74 \cdot 9$ & 0.348 & $76 \cdot 1$ & $62 \cdot 6$ & $88 \cdot 6$ & $70 \cdot 1$ & $62 \cdot 5$ & 83.4 & 0.206 \\
\hline$\%$ Energy & $17 \cdot 1$ & $14 \cdot 7$ & $18 \cdot 3$ & $15 \cdot 5$ & $13 \cdot 4$ & $17 \cdot 7$ & 0.022 & $16 \cdot 5$ & $15 \cdot 1$ & $18 \cdot 0$ & $15 \cdot 6$ & $13 \cdot 9$ & $17 \cdot 4$ & 0.086 \\
\hline Fat $(\mathrm{g})$ & $59 \cdot 8$ & $45 \cdot 6$ & $66 \cdot 9$ & $59 \cdot 0$ & $48 \cdot 9$ & $68 \cdot 2$ & $0 \cdot 831$ & $68 \cdot 6$ & $58 \cdot 0$ & $74 \cdot 7$ & $65 \cdot 2$ & $53 \cdot 4$ & $74 \cdot 5$ & 0.366 \\
\hline$\%$ Energy & $32 \cdot 1$ & $28 \cdot 3$ & $35 \cdot 5$ & $31 \cdot 9$ & $28 \cdot 2$ & $34 \cdot 1$ & 0.449 & $32 \cdot 4$ & $29 \cdot 0$ & $35 \cdot 2$ & $29 \cdot 7$ & $26 \cdot 9$ & $33 \cdot 7$ & 0.067 \\
\hline SFA (g) & $27 \cdot 3$ & $20 \cdot 1$ & $31 \cdot 6$ & $25 \cdot 3$ & $20 \cdot 4$ & $28 \cdot 8$ & 0.710 & $29 \cdot 0$ & $24 \cdot 3$ & 31.9 & $26 \cdot 8$ & $22 \cdot 9$ & $33 \cdot 7$ & 0.515 \\
\hline \% Energy & $14 \cdot 1$ & $12 \cdot 6$ & $16 \cdot 2$ & $13 \cdot 4$ & $11 \cdot 4$ & $15 \cdot 2$ & $0 \cdot 121$ & $13 \cdot 5$ & $12 \cdot 2$ & $14 \cdot 8$ & $13 \cdot 0$ & $11 \cdot 0$ & $14 \cdot 6$ & $0 \cdot 216$ \\
\hline MUFA (g) & $17 \cdot 1$ & $13 \cdot 7$ & $19 \cdot 9$ & $17 \cdot 4$ & $13 \cdot 1$ & $20 \cdot 3$ & 0.893 & $21 \cdot 0$ & $17 \cdot 4$ & $24 \cdot 3$ & $17 \cdot 9$ & $15 \cdot 7$ & $22 \cdot 0$ & 0.022 \\
\hline \% Energy & $9 \cdot 2$ & $8 \cdot 1$ & $10 \cdot 8$ & $9 \cdot 2$ & $7 \cdot 8$ & $10 \cdot 3$ & 0.307 & $9 \cdot 7$ & $8 \cdot 4$ & $11 \cdot 1$ & $8 \cdot 5$ & $7 \cdot 6$ & $9 \cdot 5$ & $<0.001$ \\
\hline PUFA (g) & $6 \cdot 4$ & $4 \cdot 9$ & $8 \cdot 1$ & $7 \cdot 0$ & $5 \cdot 6$ & $8 \cdot 6$ & 0.328 & $8 \cdot 1$ & $6 \cdot 5$ & $9 \cdot 3$ & $8 \cdot 2$ & 6.9 & $9 \cdot 6$ & 0.348 \\
\hline \% Energy & $3 \cdot 6$ & $2 \cdot 9$ & $4 \cdot 3$ & $3 \cdot 5$ & $3 \cdot 0$ & $4 \cdot 8$ & 0.547 & $3 \cdot 7$ & $3 \cdot 2$ & $4 \cdot 3$ & $3 \cdot 7$ & $3 \cdot 2$ & $4 \cdot 6$ & 0.418 \\
\hline PUFA $n-6$ cis (g) & $4 \cdot 6$ & $3 \cdot 6$ & $6 \cdot 0$ & $5 \cdot 2$ & $4 \cdot 4$ & $6 \cdot 1$ & $0 \cdot 184$ & $5 \cdot 7$ & $4 \cdot 7$ & $6 \cdot 8$ & $6 \cdot 0$ & $5 \cdot 0$ & $7 \cdot 0$ & 0.206 \\
\hline PUFA $n-3$ cis $(\mathrm{g})$ & $1 \cdot 4$ & $1 \cdot 0$ & $2 \cdot 1$ & $1 \cdot 5$ & $1 \cdot 0$ & $2 \cdot 1$ & 0.491 & 1.9 & $1 \cdot 4$ & $2 \cdot 3$ & $1 \cdot 6$ & $1 \cdot 2$ & $2 \cdot 2$ & 0.374 \\
\hline$n-6: n-3$ & $3 \cdot 2$ & $2 \cdot 4$ & $4 \cdot 2$ & $3 \cdot 8$ & $3 \cdot 1$ & $5 \cdot 0$ & 0.034 & $3 \cdot 2$ & $2 \cdot 6$ & $3 \cdot 8$ & $3 \cdot 8$ & $2 \cdot 5$ & $5 \cdot 4$ & 0.010 \\
\hline Carbohydrate (g) & $204 \cdot 1$ & $176 \cdot 6$ & $249 \cdot 1$ & $217 \cdot 7$ & $193 \cdot 5$ & $262 \cdot 3$ & $0 \cdot 114$ & $238 \cdot 5$ & $204 \cdot 7$ & $270 \cdot 7$ & $248 \cdot 0$ & $214 \cdot 8$ & $279 \cdot 6$ & $0 \cdot 100$ \\
\hline \% Energy & $51 \cdot 0$ & $47 \cdot 6$ & $54 \cdot 3$ & $52 \cdot 8$ & $48 \cdot 6$ & $57 \cdot 2$ & 0.079 & $51 \cdot 0$ & $48 \cdot 3$ & $54 \cdot 1$ & $54 \cdot 0$ & $50 \cdot 8$ & $57 \cdot 0$ & 0.010 \\
\hline Added sugar (g) & $45 \cdot 7$ & $36 \cdot 0$ & $62 \cdot 4$ & $51 \cdot 8$ & 33.5 & $76 \cdot 3$ & 0.317 & $50 \cdot 9$ & $37 \cdot 1$ & $67 \cdot 2$ & $57 \cdot 2$ & $37 \cdot 4$ & $87 \cdot 9$ & 0.091 \\
\hline \% Energy & $12 \cdot 2$ & $8 \cdot 5$ & $15 \cdot 0$ & $12 \cdot 5$ & $9 \cdot 3$ & $15 \cdot 2$ & 0.476 & $10 \cdot 7$ & $8 \cdot 2$ & $14 \cdot 8$ & $12 \cdot 7$ & $9 \cdot 4$ & $17 \cdot 2$ & 0.094 \\
\hline Fibre $(\mathrm{g})$ & $14 \cdot 1$ & $11 \cdot 2$ & $16 \cdot 7$ & $14 \cdot 7$ & $11 \cdot 9$ & $17 \cdot 9$ & $0 \cdot 175$ & $17 \cdot 1$ & $13 \cdot 0$ & $19 \cdot 6$ & $15 \cdot 2$ & $13 \cdot 1$ & $18 \cdot 1$ & 0.138 \\
\hline
\end{tabular}

$P$ values shown are for the difference between control and intervention schools at baseline and follow-up (independent $t$ test).

gender difference was found for the intake of fish liver oil in the control schools, being greater among boys. No other gender differences were detected at follow-up when separately analysed for intervention and control schools. A gender difference was found in the intake of milk drinks, the intake being greater among boys, when analysed for both school groups together.

The intake of the following macronutrients was not within the Nordic Reference Value (NRV) at baseline (the difference between the school groups was insignificant): the intakes of SFA and added sugar were above the NRV, whereas the intakes of MUFA, PUFA and fibre were below. The mean intake of micronutrients was above the recommended intake, except for iodine and vitamin D. The baseline data have been described elsewhere ${ }^{(18)}$. At follow-up, the percentage of EI from MUFA in the intervention schools was within the NRV (10-15\%). The mean iodine intake reached the recommended intake in both school groups at follow-up. Other nutrients below or above the NRV at baseline were the same at follow-up.

\section{Discussion}

Overall, these findings suggest that the school-based intervention was successful in increasing fruit and vegetable intake, in both girls and boys. The total fruit and vegetable intake increased by $47 \%$ at follow-up in the intervention group, whereas the intake decreased in the control group at the same time. The majority of the children did not meet the FBDG for fruit and vegetable intake. Other changes in food intake were less significant.

In the present intervention, fruit and vegetable intake increased by approximately $60 \mathrm{~g} / \mathrm{d}$ in the intervention schools, whereas the intake decreased by approximately $45 \mathrm{~g} / \mathrm{d}$ in the control schools. The effects of the intervention are comparable to the most successful interventions. A systematic review in 2006 of interventions aiming at increasing fruit and vegetable intake in children shows that the results of ten of the fifteen studies met the criteria for a significant effect set by the reviewers, ranging from $>0.3$ to 0.99 portion $/ \mathrm{d}^{(16)}$. A closer look at the three most effective studies reviewed suggests that the more students are exposed to fruits and vegetables, the more the consumption pattern improves ${ }^{(16)}$. More recent European studies in three countries, Norway, the Netherlands and Spain, have found a positive effect of providing free fruits and vegetables at school ${ }^{(14,28,29)}$. In the present intervention, the teachers encouraged children to bring fruits and vegetables to school, and the children also ate more fruits and vegetables provided with school meals. Current behaviour-change theory proposes that behavioural change is most likely if individuals have the motivation, ability and opportunity to change ${ }^{(30)}$. Nutrition education has been found to be an effective way to increase fruit and vegetable intake, especially when children have fruits and vegetables available ${ }^{(28,31)}$. The nutrition education in the present intervention aimed to motivate the children to eat more fruits and vegetables both at and outside school. Children were also encouraged by teachers to bring fruits 
Table 5 Micronutrients, median intake (25th and 75th percentiles), shown at baseline and follow-up separately for intervention and control schools

\begin{tabular}{|c|c|c|c|c|c|c|c|c|c|c|c|c|c|c|}
\hline \multirow[b]{4}{*}{ Micronutrients } & \multicolumn{7}{|c|}{ Baseline } & \multicolumn{7}{|c|}{ Follow-up } \\
\hline & \multicolumn{3}{|c|}{ Intervention (n 58) } & \multicolumn{3}{|c|}{ Control (n 48) } & \multirow[b]{3}{*}{$P$ value } & \multicolumn{3}{|c|}{ Intervention ( $n$ 58) } & \multicolumn{3}{|c|}{ Control (n 48) } & \multirow[b]{3}{*}{$P$ value } \\
\hline & \multirow[b]{2}{*}{ Median } & \multicolumn{2}{|c|}{ Percentiles } & \multirow[b]{2}{*}{ Median } & \multicolumn{2}{|c|}{ Percentiles } & & \multirow[b]{2}{*}{ Median } & \multicolumn{2}{|c|}{ Percentiles } & \multirow[b]{2}{*}{ Median } & \multicolumn{2}{|c|}{ Percentiles } & \\
\hline & & 25th & 75th & & 25th & 75th & & & 25th & 75th & & 25th & 75th & \\
\hline Calcium (mg) & $897 \cdot 0$ & $754 \cdot 4$ & $1046 \cdot 0$ & 759.9 & 672.9 & $1121 \cdot 4$ & 0.577 & $946 \cdot 0$ & $791 \cdot 8$ & $1141 \cdot 3$ & $883 \cdot 7$ & $724 \cdot 1$ & $1203 \cdot 6$ & 0.562 \\
\hline Magnesium (mg) & $207 \cdot 5$ & $187 \cdot 7$ & $250 \cdot 7$ & $216 \cdot 4$ & $181 \cdot 0$ & $255 \cdot 8$ & 0.799 & $248 \cdot 9$ & $219 \cdot 1$ & $278 \cdot 7$ & $224 \cdot 9$ & $193 \cdot 0$ & $260 \cdot 8$ & 0.006 \\
\hline Phosphorus (mg) & $1238 \cdot 0$ & $1084 \cdot 7$ & $1426 \cdot 2$ & $1199 \cdot 1$ & $1022 \cdot 4$ & $1477 \cdot 6$ & 0.720 & $1361 \cdot 6$ & $1210 \cdot 0$ & $1597 \cdot 3$ & $1263 \cdot 8$ & $1127 \cdot 1$ & $1501 \cdot 9$ & 0.066 \\
\hline Iron (mg) & $12 \cdot 1$ & $8 \cdot 2$ & $16 \cdot 4$ & $11 \cdot 8$ & 8.9 & $15 \cdot 6$ & 0.948 & 13.9 & $10 \cdot 7$ & $18 \cdot 7$ & $14 \cdot 3$ & $9 \cdot 7$ & $18 \cdot 9$ & 0.675 \\
\hline Copper (mg) & 0.9 & $0 \cdot 8$ & $1 \cdot 1$ & $1 \cdot 0$ & $0 \cdot 8$ & $1 \cdot 3$ & 0.057 & $1 \cdot 1$ & 0.9 & $1 \cdot 2$ & $1 \cdot 0$ & 0.9 & $1 \cdot 2$ & 0.500 \\
\hline Zinc (mg) & $9 \cdot 1$ & $7 \cdot 3$ & $11 \cdot 2$ & 8.9 & $7 \cdot 8$ & $10 \cdot 8$ & 0.808 & $9 \cdot 8$ & $8 \cdot 1$ & $12 \cdot 6$ & $9 \cdot 3$ & $8 \cdot 2$ & $11 \cdot 7$ & 0.347 \\
\hline Selenium $(\mu \mathrm{g})$ & $50 \cdot 9$ & $41 \cdot 2$ & 65.5 & $47 \cdot 1$ & $38 \cdot 4$ & $57 \cdot 6$ & $0 \cdot 138$ & $60 \cdot 2$ & $49 \cdot 7$ & 69.9 & $58 \cdot 3$ & $46 \cdot 1$ & $70 \cdot 8$ & 0.398 \\
\hline lodine $(\mu \mathrm{g})$ & $117 \cdot 2$ & $77 \cdot 0$ & $166 \cdot 7$ & $85 \cdot 6$ & $58 \cdot 2$ & $116 \cdot 7$ & 0.043 & 134.6 & $98 \cdot 2$ & 182.9 & $107 \cdot 1$ & $75 \cdot 0$ & $131 \cdot 6$ & 0.001 \\
\hline Retinol $(\mu \mathrm{g})^{\star}$ & $438 \cdot \overline{5}$ & $330 \cdot 5$ & $747 \cdot 1$ & $547 \cdot 8$ & $349 \cdot 7$ & $1161 \cdot 0$ & $0 \cdot 104$ & 478.5 & $362 \cdot 9$ & $720 \cdot 2$ & $532 \cdot 1$ & $315 \cdot 8$ & $1017 \cdot 0$ & 0.344 \\
\hline$\beta$-Carotene $(\mu \mathrm{g})^{*}$ & $750 \cdot 5$ & 394.7 & 1403.5 & $555 \cdot 0$ & $324 \cdot 8$ & $1491 \cdot 8$ & 0.616 & 966.5 & $465 \cdot 2$ & $2036 \cdot 5$ & $511 \cdot 4$ & $309 \cdot 2$ & $1129 \cdot 5$ & 0.004 \\
\hline Vitamin A $(R E ; \mu g)^{*}$ & $539 \cdot 3$ & $417 \cdot 5$ & $804 \cdot 1$ & $698 \cdot 2$ & $393 \cdot 2$ & $1228 \cdot 7$ & $0 \cdot 118$ & $652 \cdot 8$ & $450 \cdot 2$ & $860 \cdot 9$ & $662 \cdot 5$ & $400 \cdot 0$ & $1214 \cdot 5$ & 0.751 \\
\hline Vitamin $D(\mu \mathrm{g})^{\star}$ & $4 \cdot 1$ & $1 \cdot 6$ & $11 \cdot 2$ & $3 \cdot 1$ & $1 \cdot 6$ & 8.9 & 0.477 & $4 \cdot 6$ & $2 \cdot 7$ & $11 \cdot 6$ & 3.5 & $2 \cdot 0$ & $9 \cdot 9$ & 0.213 \\
\hline Vitamin $\mathrm{E}(\alpha-\mathrm{TE} ; \mathrm{mg})^{*}$ & $5 \cdot 8$ & $4 \cdot 0$ & $8 \cdot 1$ & $5 \cdot 1$ & $4 \cdot 3$ & $8 \cdot 4$ & 0.859 & $6 \cdot 2$ & $4 \cdot 9$ & $8 \cdot 8$ & $6 \cdot 0$ & $5 \cdot 1$ & $9 \cdot 5$ & 0.990 \\
\hline Thiamin (mg) & $1 \cdot 3$ & $1 \cdot 0$ & $1 \cdot 6$ & $1 \cdot 2$ & $1 \cdot 0$ & $1 \cdot 5$ & 0.586 & $1 \cdot 4$ & $1 \cdot 1$ & $1 \cdot 8$ & $1 \cdot 4$ & $1 \cdot 1$ & $1 \cdot 6$ & 0.465 \\
\hline Riboflavin (mg) & $1 \cdot 7$ & $1 \cdot 4$ & $2 \cdot 2$ & $1 \cdot 8$ & $1 \cdot 3$ & $2 \cdot 2$ & 0.966 & $2 \cdot 0$ & 1.5 & $2 \cdot 4$ & 1.9 & 1.5 & $2 \cdot 2$ & 0.501 \\
\hline Niacin equivalents (mg) & $25 \cdot 9$ & $21 \cdot 0$ & $31 \cdot 0$ & $24 \cdot 5$ & $20 \cdot 4$ & $28 \cdot 4$ & 0.488 & $29 \cdot 2$ & $26 \cdot 0$ & $36 \cdot 0$ & $25 \cdot 8$ & $21 \cdot 9$ & $31 \cdot 6$ & 0.066 \\
\hline Vitamin $B_{6}(m q)^{*}$ & 1.6 & $1 \cdot 2$ & $2 \cdot 0$ & $1 \cdot 7$ & $1 \cdot 3$ & $2 \cdot 0$ & 0.753 & 1.9 & 1.5 & $2 \cdot 5$ & $1 \cdot 7$ & 1.4 & $2 \cdot 0$ & 0.098 \\
\hline Folate $(\mu \mathrm{g})$ & $280 \cdot 2$ & $216 \cdot 4$ & $356 \cdot 4$ & $263 \cdot 6$ & $188 \cdot 6$ & $352 \cdot 8$ & 0.816 & $344 \cdot 0$ & $255 \cdot 9$ & $410 \cdot 0$ & 306.9 & $235 \cdot 1$ & $367 \cdot 5$ & 0.253 \\
\hline Vitamin $B_{12}(\mu \mathrm{g})^{\star}$ & $4 \cdot 4$ & $3 \cdot 7$ & $6 \cdot 1$ & $4 \cdot 1$ & $3 \cdot 4$ & $6 \cdot 7$ & 0.861 & $5 \cdot 3$ & $4 \cdot 1$ & $6 \cdot 3$ & 4.5 & $3 \cdot 2$ & $5 \cdot 8$ & 0.088 \\
\hline Vitamin C (mg) & $76 \cdot 5$ & 45.9 & $104 \cdot 7$ & $88 \cdot 1$ & $50 \cdot 7$ & $114 \cdot 6$ & 0.324 & $114 \cdot 7$ & 71.6 & $172 \cdot 5$ & $75 \cdot 5$ & $39 \cdot 2$ & 156.9 & 0.198 \\
\hline
\end{tabular}

$\mathrm{RE}$, retinol equivalents; $\alpha$-TE, $\alpha$-tocopherol equivalents.

$P$ values shown are for the difference between control and intervention schools at baseline and follow-up (independent $t$ test).

${ }^{*}$ The intake distribution was skewed; therefore a non-parametric test was used (Mann-Whitney $U$ test). 
Table 6 Difference between the intake of nutrients per day according to the food records at baseline and follow-up in intervention and control schools

\begin{tabular}{|c|c|c|c|c|c|}
\hline \multirow[b]{2}{*}{ Nutrients } & \multicolumn{2}{|c|}{ Intervention ( $n$ 58) } & \multicolumn{2}{|c|}{ Control (n 48) } & \multirow[b]{2}{*}{$P$ value } \\
\hline & Mean & SD & Mean & SD & \\
\hline Energy (kJ) & $834 \cdot 8$ & $1441 \cdot 0$ & $678 \cdot 4$ & $1712 \cdot 4$ & $0 \cdot 617$ \\
\hline Protein $(\mathrm{g})$ & $7 \cdot 9$ & $14 \cdot 5$ & $6 \cdot 9$ & $14 \cdot 0$ & $0 \cdot 704$ \\
\hline \% Energy & $-0 \cdot 3$ & $3 \cdot 4$ & 0.0 & $3 \cdot 0$ & $0 \cdot 700$ \\
\hline Fat $(g)$ & $8 \cdot 1$ & $17 \cdot 5$ & $4 \cdot 6$ & $21 \cdot 6$ & 0.369 \\
\hline$\%$ Energy & -0.2 & $5 \cdot 5$ & $-1 \cdot 3$ & $6 \cdot 3$ & 0.340 \\
\hline SFA (g) & $2 \cdot 4$ & $8 \cdot 7$ & $2 \cdot 0$ & $11 \cdot 3$ & 0.843 \\
\hline$\%$ Energy & $-0 \cdot 7$ & $3 \cdot 2$ & -0.5 & $3 \cdot 6$ & 0.798 \\
\hline MUFA (g) & $3 \cdot 1$ & $5 \cdot 6$ & $1 \cdot 0$ & $6 \cdot 5$ & 0.075 \\
\hline$\%$ Energy & 0.3 & $2 \cdot 0$ & -0.6 & $2 \cdot 2$ & 0.029 \\
\hline PUFA (g) & $1 \cdot 0$ & $3 \cdot 4$ & 0.9 & $3 \cdot 1$ & 0.865 \\
\hline$\%$ Energy & 0.0 & $1 \cdot 6$ & 0.0 & 1.5 & 0.983 \\
\hline PUFA $n-6$ cis $(\mathrm{g})$ & 0.8 & $2 \cdot 7$ & 0.7 & $2 \cdot 6$ & 0.800 \\
\hline PUFA $n-3$ cis $(\mathrm{g})$ & 0.2 & $0 \cdot 9$ & 0.2 & $0 \cdot 8$ & $0 \cdot 820$ \\
\hline$n-6: n-3$ & 0.0 & 1.5 & 0.2 & $2 \cdot 2$ & 0.492 \\
\hline Carbohydrate (g) & $23 \cdot 5$ & $55 \cdot 2$ & $23 \cdot 0$ & $61 \cdot 2$ & 0.964 \\
\hline$\%$ Energy & 0.5 & $6 \cdot 1$ & $1 \cdot 3$ & $6 \cdot 2$ & 0.467 \\
\hline Added sugar (g) & 4.9 & $27 \cdot 8$ & $10 \cdot 2$ & $35 \cdot 9$ & 0.406 \\
\hline \% Energy & 0.0 & $5 \cdot 1$ & $1 \cdot 2$ & $5 \cdot 8$ & $0 \cdot 296$ \\
\hline Fibre $(\mathrm{g})$ & $3 \cdot 0$ & $5 \cdot 0$ & 0.7 & $4 \cdot 2$ & 0.013 \\
\hline Sodium (mg) & $346 \cdot 4$ & $645 \cdot 3$ & 276.9 & $671 \cdot 1$ & 0.590 \\
\hline Potassium (mg) & $228 \cdot 1$ & $604 \cdot 9$ & $-115 \cdot 5$ & $607 \cdot 4$ & 0.005 \\
\hline Na:K ratio & 0.0 & 0.3 & 0.2 & 0.3 & 0.095 \\
\hline Calcium (mg) & $41 \cdot 1$ & $254 \cdot 4$ & $39 \cdot 5$ & $278 \cdot 0$ & 0.977 \\
\hline Magnesium (mg) & $30 \cdot 2$ & $55 \cdot 0$ & $2 \cdot 7$ & $54 \cdot 6$ & 0.012 \\
\hline Phosphorus (mg) & $140 \cdot 7$ & $262 \cdot 1$ & $59 \cdot 7$ & $242 \cdot 6$ & $0 \cdot 102$ \\
\hline Iron (mg) & $1 \cdot 7$ & $7 \cdot 1$ & $1 \cdot 2$ & $6 \cdot 6$ & 0.693 \\
\hline Copper (mg) & $0 \cdot 1$ & $0 \cdot 3$ & $0 \cdot 0$ & $0 \cdot 4$ & 0.035 \\
\hline Zinc (mg) & 0.7 & $3 \cdot 7$ & 0.4 & $3 \cdot 5$ & 0.606 \\
\hline Selenium $(\mu \mathrm{g})$ & $8 \cdot 4$ & $19 \cdot 9$ & $9 \cdot 9$ & $17 \cdot 4$ & 0.667 \\
\hline lodine $(\mu \mathrm{g})$ & $27 \cdot 3$ & $78 \cdot 6$ & $9 \cdot 8$ & $54 \cdot 3$ & $0 \cdot 180$ \\
\hline Retinol $(\mu \mathrm{g})^{*}$ & $62 \cdot 4$ & $610 \cdot 8$ & $-117 \cdot 1$ & $1355 \cdot 2$ & 0.603 \\
\hline$\beta$-Carotene $(\mu \mathrm{g})^{\star}$ & $415 \cdot 9$ & $1486 \cdot 0$ & $-40 \cdot 7$ & $1234 \cdot 4$ & 0.012 \\
\hline Vitamin $A(R E ; \mu g)^{*}$ & $97 \cdot 1$ & $615 \cdot 9$ & $-120 \cdot 5$ & $1346 \cdot 7$ & 0.446 \\
\hline Vitamin $D(\mu \mathrm{g})$ & 0.6 & $7 \cdot 1$ & 0.9 & $6 \cdot 2$ & 0.782 \\
\hline Vitamin $\mathrm{E}(\alpha-\mathrm{TE} ; \mathrm{mg})$ & 0.8 & $3 \cdot 1$ & $1 \cdot 2$ & $3 \cdot 3$ & 0.554 \\
\hline Thiamin (mg) & $0 \cdot 1$ & $0 \cdot 6$ & $0 \cdot 1$ & 0.7 & 0.953 \\
\hline Riboflavin (mg) & $0 \cdot 1$ & $0 \cdot 7$ & $0 \cdot 0$ & $0 \cdot 7$ & 0.581 \\
\hline Niacin equivalents $(\mathrm{mg})$ & $3 \cdot 6$ & $8 \cdot 5$ & $1 \cdot 8$ & $9 \cdot 5$ & $0 \cdot 311$ \\
\hline Vitamin $\mathrm{B}_{6}(\mathrm{mg})$ & 0.3 & 0.8 & $0 \cdot 1$ & 0.9 & $0 \cdot 108$ \\
\hline Folate $(\mu \mathrm{g})$ & $41 \cdot 3$ & $138 \cdot 7$ & $21 \cdot 8$ & $120 \cdot 9$ & 0.441 \\
\hline Vitamin $B_{12}(\mu \mathrm{g})$ & 0.5 & 2.5 & -0.1 & $3 \cdot 8$ & 0.355 \\
\hline Vitamin C (mg) & $34 \cdot 3$ & $66 \cdot 9$ & $6 \cdot 8$ & $77 \cdot 2$ & 0.056 \\
\hline
\end{tabular}

RE, retinol equivalents; $\alpha$-TE, $\alpha$-tocopherol equivalents.

$P$ values are shown for the intervention effect (independent $t$ test).

*Distribution of mean difference was skewed; therefore, a non-parametric test was used (Mann-Whitney $U$ test).

and vegetables to eat together during the break, and parents were informed on the importance of availability of fruits and vegetables at home. In the Pro Children crossEurope study, bringing fruits and vegetables to school was strongly associated with children's fruit and vegetable intake ${ }^{(10)}$. Availability at home was one of the strongest determinants of fruit and vegetable intake for Icelandic children in the Pro Children study ${ }^{(12)}$ at that time; however, school meals were not provided. In the autumn of 2005 it was decided that all elementary schools in Reykjavik should serve warm meals at lunch time. In the FBDG for the school canteens ${ }^{(32)}$, published by the Public Health Institute, all schools are encouraged to provide fruits or vegetables as part of school meals. Encouraging children to bring fruits or vegetables from home may be a good strategy for promoting fruit and vegetable intake, as parents know what their children like and how to prepare it. Providing fruits and vegetables with the school meals is nevertheless important, as availability at home may vary.

In the present study, a decrease in fruit intake was found in the control schools, which is similar to the decrease with age in fruit and vegetable intake observed in other studies. In a study on Finnish children followed from the age of 7 months to 11 years, the children's fruit and vegetable consumption was remarkably low and further decreased with age ${ }^{(33)}$. In an American study on children's eating patterns followed from the third to the eighth grade, fruit consumption fell by $41 \%$ between the third and eighth grades and vegetable consumption by $25 \%{ }^{(34)}$. The total fruit and vegetable intake in the control schools is comparable to the total fruit and vegetable intake of Icelandic 9-year-olds in 2003-2004 (mean intake: $143 \mathrm{~g} / \mathrm{d}$ ), in whom 
Table 7 Percentage of children meeting the food-based dietary guidelines and the distribution of intake for some of the food groups in intervention and control schools at baseline and at follow-up

\begin{tabular}{|c|c|c|c|c|c|c|c|c|c|}
\hline \multirow[b]{3}{*}{ Food group } & \multirow[b]{3}{*}{ Measure } & \multicolumn{4}{|c|}{ Baseline } & \multicolumn{4}{|c|}{ Follow-up } \\
\hline & & \multicolumn{2}{|c|}{ Intervention ( $n$ 58) } & \multicolumn{2}{|c|}{ Control (n 48) } & \multicolumn{2}{|c|}{ Intervention ( $n$ 58) } & \multicolumn{2}{|c|}{ Control ( $n$ 48) } \\
\hline & & $\%$ & $n$ & $\%$ & $n$ & $\%$ & $n$ & $\%$ & $n$ \\
\hline \multirow[t]{2}{*}{ Fruits } & $>150 \mathrm{~g} / \mathrm{d}$ & $27 \cdot 6$ & 16 & $50 \cdot 0$ & 24 & $36 \cdot 2$ & 21 & $33 \cdot 3$ & 16 \\
\hline & $\geq 200 \mathrm{~g} / \mathrm{d}$ & $10 \cdot 3$ & 6 & $20 \cdot 8$ & 10 & $20 \cdot 7$ & 12 & $14 \cdot 6$ & 7 \\
\hline \multirow[t]{2}{*}{ Vegetables } & $>150 \mathrm{~g} / \mathrm{d}$ & $1 \cdot 7$ & 1 & $2 \cdot 1$ & 1 & $15 \cdot 5$ & 9 & $2 \cdot 1$ & 1 \\
\hline & $\geq 200 \mathrm{~g} / \mathrm{d}$ & $0 \cdot 0$ & 0 & $2 \cdot 1$ & 1 & $5 \cdot 2$ & 3 & $0 \cdot 0$ & 0 \\
\hline \multirow[t]{2}{*}{ Fish* $^{*}$} & $\geq$ Twice a week & $65 \cdot 5$ & 38 & $47 \cdot 9$ & 23 & $94 \cdot 8$ & 55 & $66 \cdot 7$ & 32 \\
\hline & $\geq 240 \mathrm{~g} /$ week & $32 \cdot 7$ & 19 & $12 \cdot 5$ & 6 & $46 \cdot 6$ & 27 & $18 \cdot 8$ & 9 \\
\hline \multirow[t]{2}{*}{ Fish liver oil } & Taken some days & $44 \cdot 8$ & 26 & $45 \cdot 8$ & 22 & $37 \cdot 9$ & 22 & $37 \cdot 5$ & 18 \\
\hline & $\geq 5$ and $\leq 10 \mathrm{ml} / \mathrm{d}$ & $19 \cdot 0$ & 11 & $8 \cdot 3$ & 4 & $15 \cdot 5$ & 9 & $18 \cdot 8$ & 9 \\
\hline \multirow{3}{*}{$\begin{array}{l}\text { Milk and milk } \\
\text { productst }\end{array}$} & $<1.5$ portions/d & $22 \cdot 4$ & 13 & $31 \cdot 2$ & 15 & $27 \cdot 6$ & 16 & $37 \cdot 5$ & 18 \\
\hline & $1.5-3.5$ portions/d & $72 \cdot 4$ & 42 & $64 \cdot 6$ & 31 & $69 \cdot 0$ & 40 & $52 \cdot 1$ & 25 \\
\hline & $>3.5$ portions/d & $5 \cdot 1$ & 3 & $4 \cdot 2$ & 2 & $3 \cdot 4$ & 2 & $10 \cdot 4$ & 5 \\
\hline
\end{tabular}

*Processed fish not included in these values.

tMilk and other milk products, including cheese $25 \mathrm{~g}$ of cheese corresponding to one portion of milk $(250 \mathrm{~g}=$ one glass), not including milk products in other food items.

diet was assessed with repeated $24 \mathrm{~h}$ recalls ${ }^{(21)}$. The distribution in intake at follow-up indicates that the intervention in the present study also increased intake among children with low intake at baseline; the intake was frequently low at baseline. The intervention seemed to have a similar effect on the intakes of girls and boys, as no gender difference was found in fruit and vegetable intake at either baseline or follow-up.

There was a significant increase in intake in the intervention schools of the following macro- and micronutrients: fibre, potassium, magnesium and $\beta$-carotene. This increase is related to increased intake of fruits and vegetables. The mean fibre intake was below the NRV at baseline $^{(18)}$, and although it increased in the intervention schools, it was still below the NRV at follow-up. The macro- and micronutrient intakes in the control schools, at follow-up, is comparable to that in the Icelandic study on intake of 9-year-olds ${ }^{(21)}$.

The intervention had little effect on the intake of food other than on fruits and vegetables. Studies by the Unit for Nutrition Research on diet in childhood have shown a decrease in fish intake ${ }^{(21)}$. In the present study, fish intake increased in both school groups, which could be explained by an increase at the community level. The intervention had an insignificant effect on the intake of fish liver oil. More children seemed to meet the milk recommendation in the intervention group, but this was not significant. The main focus was on promoting fruit and vegetable intake, which may explain why we did not find effects on other food items. However, other approaches may also be required to change the intake of other food items such as fish liver oil, fish and milk.

The teachers have a major role in the classroom component of the intervention. They were positive for encouraging children to bring fruits and vegetables to school. There was no major difference between the schools in the implementation of the intervention. At the start of the intervention, the educational material was implemented by the author in collaboration with the teachers in a similar way in all the three intervention schools. Children got the same homework assignments in all schools during the intervention. However, there was slight variation in the implementation, which might have been caused by difference in facilities and support by teachers for the intervention. Other studies have found that the degree of implementation and support for the intervention are associated with more positive results ${ }^{(35)}$. Teacher training has also been found to be important for the success of an intervention ${ }^{(16)}$. In the present study, there were regular meetings with teachers, and the educational material was developed with their collaboration. Parental letters were the same in all schools, as were the homework sheets, which were aimed at involving the parents in the intervention. The majority of the children returned the homework sheets. Parental involvement has been found to be associated with changes in vegetable intake ${ }^{(35)}$. In the present study, the effects of the intervention were stronger on vegetable intake than on fruit intake, which may indicate that the intervention was successful in involving parents in the promotion of fruit and vegetable intake.

The present study is part of the school-based study 'Lifestyle of 7-9-year-old children'. The aim of the study was to better integrate physical activity into the daily routine at school and to promote healthy food habits. The increased physical activity during the school day may have had some positive effects on children's food habits, but it may also have had some negative effects on the implementation of nutrition education in the schools, as one of the barriers to school-based interventions is competition with other school priorities ${ }^{(16)}$. Interventions among children at this age may be preferable, as dietary habits are still forming ${ }^{(36)}$; however, assessing the diets of children presents unique methodological challenges ${ }^{(37,38)}$. The burden of dietary reporting falls on the parents until children have reached the developmental stage of being aware of their food intake and can begin conceptualising 
time ${ }^{(39,40)}$. The method used in the present study was a $3 \mathrm{~d}$ weighed food record. The high dropout rate is most likely related to the high respondent burden of the assessment method. The nutrient intake of the 9-year-old children in the control schools was similar to a recent study on the diets of 9-year-old children, in which dietary assessment was repeated in $24 \mathrm{~h}$ recalls, which indicates that the data are comparable to other studies in Icelandic children ${ }^{(21)}$.

\section{Conclusion}

The school-based intervention was successful in increasing fruit and vegetable intake (a $47 \%$ increase from baseline) in both girls and boys. The increase in fruit and vegetable intake was mirrored in nutrient intake. The main focus was on promoting fruit and vegetable intake, which may explain why we did not find effects on other food items. The intervention was mainly based on studies of determinants of fruit and vegetable intake, and it may be that other approaches are required to change the intake of other food items such as fish liver oil, fish and milk.

\section{Acknowledgements}

The present study was supported by research grants from the Eimskip Fund of the University of Iceland, Rannís The Icelandic Centre for Research, and a private company, Brim Seafood. The authors have no conflict of interest. A.G.K. did the daily management of the research, administered the intervention and worked on the data, both at baseline and follow-up. I.T. was the supervisor of A.G.K.; they worked together on all the nutritional details of the study 'Lifestyle of 7-9-year-old children' and writing of the paper. E.J. coordinated the 'Lifestyle of 7-9year-old children' and collaborated on writing the paper. The authors thank the children and their parents for their participation, and the headmasters, teachers and other school staff for their collaboration. They thank nutritionists Svandis Erna Jonsdottir and Bryndis Elfa Gunnarsdottir for their work on entering and coding the dietary data at baseline, as well as MS student Erna Hedinsdottir for her work on data collection and entering and coding the dietary data at follow-up.

\section{References}

1. World Health Organization (2004) Global strategy on diet, physical activity and health. World Health Assembly Resolution 57.17. http://www.who.int/gb/ebwha/pdf_files/ WHA57/A57_R17Cen.pdf (accessed September 2008).

2. The Ministry of Education, Science and Culture (2007) The National Curriculum Guide for compulsory schools. (accessed September 2007). http://bella.mrn.stjr.is/utgafur/ adalnamskra_grsk_natturufraedi-umhverfismennt.pdf

3. Baranowski T, Cullen KW \& Baranowski J (1999) Psychosocial correlates of dietary intake: advancing dietary intervention. Annu Rev Nutr 19, 17-40.
4. Savage JS, Fisher JO \& Birch LL (2007) Parental influence on eating behavior: conception to adolescence. J Law Med Ethics 35, 22-34.

5. Galloway AT, Fiorito LM, Francis LA et al. (2006) 'Finish your soup': counterproductive effects of pressuring children to eat on intake and affect. Appetite 46, 318-323.

6. Brug J, Kremers SP, Lenthe F et al. (2008) Environmental determinants of healthy eating: in need of theory and evidence. Proc Nutr Soc 67, 307-316.

7. Wardle J, Herrera ML, Cooke L et al. (2003) Modifying children's food preferences: the effects of exposure and reward on acceptance of an unfamiliar vegetable. Eur $J$ Clin Nutr 57, 341-348.

8. Bere E \& Klepp K-I (2004) Correlates of fruit and vegetable intake among Norwegian schoolchildren: parental and selfreports. Public Health Nutr 8, 991-998.

9. Rasmussen M, Krølner R, Klepp KI et al. (2006) Determinants of fruit and vegetable consumption among children and adolescents: a review of the literature. Part I: quantitative studies. Int J Behav Nutr Phys Act 11, 3-22.

10. De Bourdeaudhuij I, te Velde S, Brug J et al. (2008) Personal, social and environmental predictors of daily fruit and vegetable intake in 11-year-old children in nine European countries. Eur J Clin Nutr 62, 834-841.

11. Brug J, Tak NI, te Velde SJ et al. (2008) Taste preferences, liking and other factors related to fruit and vegetable intakes among schoolchildren: results from observational studies. Br J Nutr 99, S7-S14.

12. Kristjansdottir AG, Thorsdottir I, De Bourdeaudhuij I et al. (2006) Determinants of fruit and vegetable intake among 11 -year-old schoolchildren in a country of traditionally low fruit and vegetable consumption. Int J Behav Nutr Phys Act 3, 41 .

13. Kristjansdottir AG, De Bourdeaudhuij I, Klepp KI et al. (2009) Children's and parents' perceptions of the determinants of children's fruit and vegetable intake in a low-intake population. Public Health Nutr 12, 1224-1233.

14. Bere E, Veierød MB \& Klepp KI (2005) The Norwegian School Fruit Programme: evaluating paid vs. no-cost subscriptions. Prev Med 41, 463-470.

15. Pérez-Rodrigo C, Wind M, Hildonen C et al. (2005) The Pro Children intervention: applying the intervention mapping protocol to develop a school-based fruit and vegetable promotion programme. Ann Nutr Metab 49, 267-277.

16. Knai C, Pomerleau J, Lock K et al. (2006) Getting children to eat more fruit and vegetables: a systematic review. Prev Med 42, 85-95.

17. The Public Health Institute of Iceland (2006) Recommendations on diet and nutrients for adults and children from 2 year of age. http://www.lydheilsustod.is/media/manneldi/ utgefid//mataraedi-lowres.pdf (accessed December 2008).

18. Kristjansdottir AG \& Thorsdottir I (2009) Adherence to food-based dietary guidelines and evaluation of nutrient intake in 7-year-old children. Public Health Nutr 12, 1999-2008.

19. Yngve A, Wolf A, Poortvliet E et al. (2005) Fruit and vegetable intake in a sample of 11 -year-old children in 9 European countries: the Pro Children Cross-sectional Survey. Ann Nutr Metab 49, 236-245.

20. Thórsdóttir I \& Gunnarsdóttir I (2005) Vitamin D in nutrition of young Icelandic children. Laeknabladid $\mathbf{9 1}$, $581-586$

21. Thorsdottir I\& Gunnarsdottir I (2006) The Diet of Icelandic 9- and 15-year-old Children and Adolescents, Dietary Survey of Unit for Nutrition Research 2002-2003. Reykjavik: Public Health Institute and Unit for Nutrition Research. 
22. Jonsson A, Hall AH, Zoega G et al. (2001) Tekjuskipting á Íslandi. Reykjavik: Institute of Economic Studies, University of Iceland.

23. Evers CL (2006) How to Teach Nutrtion to Kids. Portland, OR: 24 Carrot Press.

24. Oskardottir G (2001) Hermannsdottir. Komdu og skoðaðulikamann. Reykjavik: The National Centre for Educational Materials.

25. Bingham SA (1994) The use of 24-h urine samples and energy expenditure to validate dietary assessments. $\mathrm{Am} \mathrm{J}$ Clin Nutr 59, 227S-231S.

26. Nordic Council of Ministers (2004) Nordic Nutrition Recommendations 2004: Integrating Nutrition and Physical Activity, 4th ed. Nord 2004:13. Copenhagen: Nordic Council of Ministers.

27. Cole TJ, Bellizzi MC, Flegal KM et al. (2000) Establishing a standard definition for child overweight and obesity worldwide: international survey. BMJ 320, 1240-1243.

28. Te Velde SJ, Brug J, Wind M et al. (2008) Effects of a comprehensive fruit- and vegetable-promoting schoolbased intervention in three European countries: the Pro Children Study. Br J Nutr 99, 893-903.

29. Bere E, Veierod MB, Skare O et al. (2007) Free school fruit sustained effect three years later. Int J Behav Nutr Phys Act 4, 5 .

30. Brug J, Oenema A \& Ferreira I (2005) Theory, evidence and Intervention Mapping to improve behavior nutrition and physical activity interventions. Int J Behav Nutr Phys Act 2, 2.

31. Anderson AS, Porteous LEG, Foster E et al. (2005) The impact of a school-based nutrition education intervention on dietary intake and cognitive and attitudinal variables relating to fruits and vegetables. Public Health Nutr 8 , 650-656.

32. The Public Health Institute of Iceland (2008) Guide for the school-canteens. http://www.lydheilsustod.is/media/manneldi/ fraedsla/Handbok_skolamotuneyti.pdf (accessed December 2008).

33. Talvia S, Räsänen L, Lagström H et al. (2006) Longitudinal trends in consumption of vegetables and fruit in Finnish children in an atherosclerosis prevention study (STRIP). Eur J Clin Nutr 60, 172-180.

34. Lytle LA, Seifert S, Greenstein J et al. (2000) How do children's eating patterns and food choices change over time? Results from a cohort study. Am J Health Promot 14, 222-228.

35. Wind M, Bjelland M, Pérez-Rodrigo C et al. (2008) Appreciation and implementation of a school-based intervention are associated with changes in fruit and vegetable intake in 10- to 13-year old schoolchildren - the Pro Children study. Health Educ Res 23, 997-1007.

36. Birch LL \& Fisher JO (1998) Development of eating behaviors among children and adolescents. Pediatrics 101, 539-549.

37. McPherson RS, Hoelscher DM, Alexander M et al. (2000) Dietary assessment methods among school-aged children: Validity and reliability. Prev Med 31, S11-S33.

38. Livingstone MB, Robson PJ \& Wallace JM (2004) Issues in dietary intake assessment of children and adolescents. $\mathrm{BrJ}$ Nutr 92, S213-S222.

39. Baranowski T \& Domel SB (1994) A cognitive model of children's reporting of food intake. Am J Clin Nutr 59, 212S-217S.

40. Livingstone MB \& Robson PJ (2000) Measurement of dietary intake in children. Proc Nutr Soc 59, 279-293. 